\title{
Photocatalytic Degradation of Sugarcane Vinasse Using ZnO Photocatalyst: Operating Parameters, Kinetic Studies, Phytotoxicity Assessments, and Reusability
}

\author{
Wei-Chin Kee ${ }^{1}$ (D) $\cdot$ Yee-Shian Wong ${ }^{1,2}$ (D) Soon-An Ong ${ }^{1,2}$ (D) Nabilah Aminah Lutpi ${ }^{1,2}$ (D) Sung-Ting Sam ${ }^{3}$ (D) \\ Audrey Chai ${ }^{1}$ (D) Kim-Mun Eng ${ }^{4}$
}

Received: 28 August 2021 / Revised: 21 October 2021 / Accepted: 11 November 2021 / Published online: 7 December 2021

(c) University of Tehran 2021

\begin{abstract}
Photocatalytic degradation performance is highly related to optimized operating parameters such as initial concentration, $\mathrm{pH}$ value, and catalyst dosage. In this study, the impact of various parameters on the photocatalytic degradation of anaerobically digested vinasse (AnVE) has been determined through decolourization and chemical oxygen demand (COD) reduction efficiency using zinc oxide $(\mathrm{ZnO})$ photocatalyst. In this context, the application of photocatalytic degradation in treating sugarcane vinasse using $\mathrm{ZnO}$ is yet to be explored. The COD reduction efficiency and decolourization achieved $83.40 \%$ and $99.29 \%$, respectively, under the conditions of $250 \mathrm{mg} / \mathrm{L}$ initial COD concentration, $\mathrm{pH} 10$, and $2.0 \mathrm{~g} / \mathrm{L}$ catalyst dosage. The phytotoxicity assessment was also conducted to determine the toxicity of AnVE before and after treatment using mung bean (Vigna radiata). The reduction of root length and the weight of mung bean indicated that the sugarcane vinasse contains enormous amounts of organic substances that affect the plant's growth. The toxicity reduction in the AnVE solution can be proved by UV-Vis absorption spectra. Furthermore, the catalyst recovery achieved $93 \%$ in the reusability test. However, the COD reduction efficiency and decolourization were reduced every cycle. It was due to the depletion of the active sites in the catalyst with the adsorption of organic molecules. Thus, it can be concluded that the photocatalytic degradation in the treatment of AnVE was effective in organic degradation, decolorization, toxicity reduction and can be reused after the recovery process.
\end{abstract}

Yee-Shian Wong

yswong@unimap.edu.my

1 Faculty of Civil Engineering Technology, Universiti Malaysia Perlis (UniMAP), Arau, 02600 Perlis, Malaysia

2 Research and Environmental Sustainability Growth, Centre of Excellence (WAREG), Universiti Malaysia Perlis (UniMAP), Arau, 02600 Perlis, Malaysia

3 Faculty of Chemical Engineering Technology, Universiti Malaysia Perlis (UniMAP), Arau, 02600 Perlis, Malaysia

4 Kenep Resources (Asia) Sdn. Bhd, No. 31 \& 33, Persiaran Jelapang Maju 2, Taman Perindustrian Ringan Jelapang Maju, 30020 Ipoh, Perak, Malaysia 


\section{Graphical abstract}

\section{Operating \\ Parameters}

\begin{tabular}{|c|c|}
\hline $\begin{array}{c}\text { Optimized } \\
\text { Parameters }\end{array}$ & Value \\
\hline $\begin{array}{c}\text { Initial COD } \\
\text { concentration }\end{array}$ & $250 \mathrm{mg} / \mathrm{L}$ \\
\hline $\mathrm{pH}$ & 10 \\
\hline Catalyst dosage & $2.0 \mathrm{~g} / \mathrm{L}$ \\
\hline
\end{tabular}

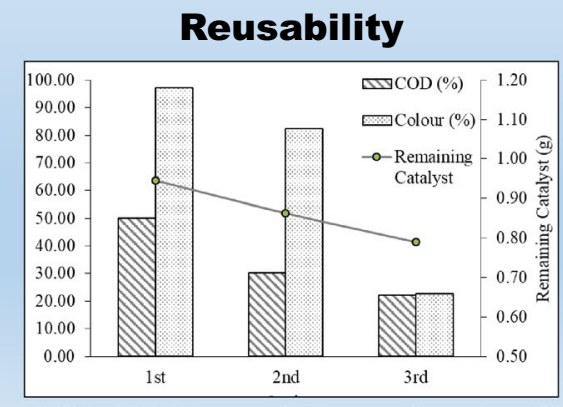

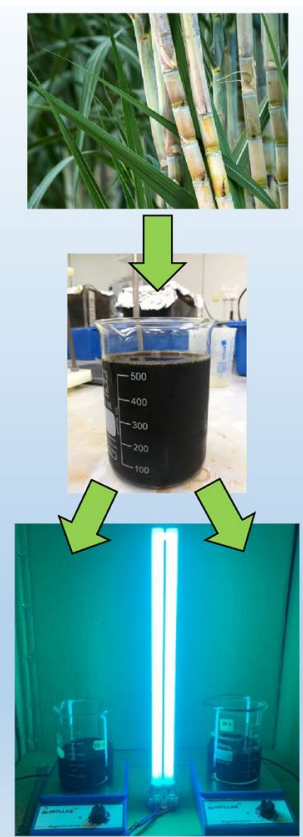

\section{UV vis spectra}

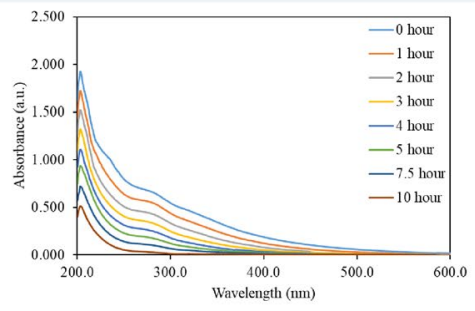

Phytotoxicity

Assessment

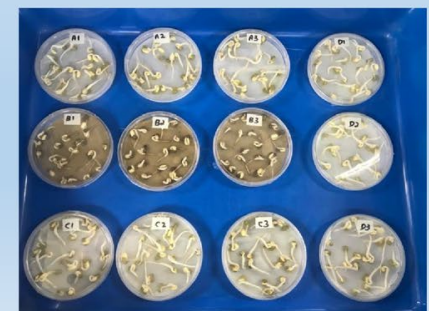

\section{Article Highlights}

- Photocatalytic degradation of AnVE was determined by using ZnO photocatalyst

- The operating parameters included initial COD concentration, pH and catalyst dosage

- The performance was determined through COD reduction efficiency and decolourization

- Phytotoxicity assessment was conducted by using mung bean (Vigna radiata)

- Reduction efficiency and catalyst recovery was determined in the reusability test

Keywords Photocatalytic degradation $\cdot$ Zinc oxide $\cdot$ Vinasse $\cdot$ Phytotoxicity assessment $\cdot$ Reusability

\section{Introduction}

In this coronavirus disease pandemic, the production of bioethanol was stimulated with the increasing usage of disinfectants. However, the increment of bioethanol production generates large quantities of wastewater, which is vinasse. Vinasse is characterized by dark brown colour, acidic $\mathrm{pH}$, and high content of organic compounds that are presented by biochemical oxygen demand (BOD) and chemical oxygen demand (COD) (Rulli et al. 2020). Biorecalcitrant compounds in vinasse can cause pollution to the aquatic ecosystem. Furthermore, the light is cut off because of its intense brown colour, and the inhibition of photosynthesis occurs. The effluent from these distilleries is the most troublesome as it contains many organic compounds like ethanol, acetic acid, carbohydrates, ketones, and some inorganic compounds (Vineetha et al. 2013). In addition, the presence of phenolic compounds in the vinasse also inhibits the degradation of organic compounds (Santana and Fernandes Machado 2008).

To overcome the wastewater pollution, vinasse has been reused as fertilizer in sugarcane crops, but excessive use can cause minor organic contamination in soil and groundwater (daSilva et al. 2021). Thus, various types of wastewater treatments have been applied in the treatment of vinasse, which involves biological treatment (Petta et al. 2017; Estrada-Arriaga et al. 2021), physical treatment (Lebron et al. 2020), chemical treatment (Prazeres et al. 2019), and advanced oxidation process (Otieno and Apollo 2021). Among all these treatment processes, anaerobic digestion is commonly applied as the primary treatment of vinasse to remove the organic compounds and generate methane production (Janke et al. 2015). However, the anaerobically digested vinasse still contains recalcitrant compounds that are not biodegradable. Thus, it is necessary to implement further treatment processes to produce 
effluent that fulfils the discharge standard. As vinasse is characterized by dark brown colour, a post-treatment to improve the decolourization is required. In this perspective, photocatalytic degradation seems to be a good option to treat the anaerobically digested vinasse. The generation of hydroxyl radicals from photocatalytic degradation is highly oxidative that is able to degrade the melanoidin and form intermediate products (Navgire et al. 2012). The total mineralization of anaerobically digested vinasse can be achieved and obtains a high decolourization rate. Hence, tremendous efforts have been invested in enhancing the performance of photocatalytic degradation in the treatment of vinasse. Among various types of photocatalyst, zinc oxide $(\mathrm{ZnO})$ is known as a suitable catalyst to carry out photocatalytic degradation because of its cost-effectiveness and high photocatalytic activity (Ong et al. 2020).

However, there are still many challenges in this research field, particularly in determining the influence of different parameters on the performance of photocatalytic degradation, which include initial concentration, $\mathrm{pH}$, and dosage of catalyst. Initial concentration is crucial in photocatalytic degradation, as it is one of the main parameters affecting treatment efficiency. The number of pollutants adsorbed on the surface of the photocatalyst can affect the rate of photocatalytic degradation while the amount of the catalyst is fixed (Reza et al. 2017). Besides that, the $\mathrm{pH}$ in the medium can influence the charge of the catalyst, pollutant, and the position of the conduction band (Elbadawy et al. 2021). Furthermore, the solution $\mathrm{pH}$ also affects the pollutant hydrolysis, the ionization degree of pollutant and oxidants, the surface characteristics of the catalyst, the activity rate of the oxidant and reactive species, and the route of degradation (Hassani et al. 2018). The optimum catalyst dosage can enhance the operation performance and also avoid the waste of catalysts. The degradation rate was directly proportional to the amount of catalyst until a certain limit of catalyst amount (Ra et al. 2021). Thus, these operational parameters must be employed and optimized for the photocatalytic degradation of vinasse.

Phytotoxicity assessments by plants have been widely used to monitor the toxicity towards the environment due to their low maintenance cost. They are usually determined through germination rate, biomass weight, and root elongation (Rizzo 2011). The root is the main part of a plant affects by the absorption and accumulation of toxicants. The reduction of root length can indicate the presence of toxicants in the soil or water bodies. According to Valerio et al. (2007), the soil toxicity was determined using lettuce through root necrosis, root elongation, and seed germination rate under different concentrations of soluble elements. The design of photocatalytic degradation in conducting combined processes with biological treatment can be determined through the toxicity of the intermediates products. Photocatalytic degradation can be selected as the pre-treatment if the biorecalcitrant components can be degraded into more biodegradable intermediates. In other words, photocatalytic degradation can be employed as a post-treatment method to remove the remaining biorecalcitrant compounds after the biological treatment.

In this present work, zinc oxide $(\mathrm{ZnO})$ was selected as the photocatalyst. The operating parameters were investigated, including initial COD concentration, $\mathrm{pH}$, and catalyst dosage on the COD reduction efficiency and decolourization on the photocatalytic degradation of AnVE. In this context, the study regarding the photocatalytic process of alcoholicbased wastewater through $\mathrm{ZnO}$ photocatalyst was rarely reported. Besides that, the phytotoxicity assessments were conducted using mung bean (Vigna radiata), and this can be a novel study to identify the toxicity of AnVE before and after the photocatalytic treatment. Reusability test was also carried out through three cumulative cycles of photocatalytic process, and the results can be determined in COD reduction efficiency, decolorization, and the catalyst remained in the system.

\section{Materials and Methods}

\section{Material and Wastewater Preparation}

Zinc oxide $(\mathrm{ZnO})$ powder (HmbG Chemicals) was used in this research with a purity of $98 \%$. Sodium hydroxide $(\mathrm{NaOH})$ and sulphuric acid $\left(\mathrm{H}_{2} \mathrm{SO}_{4}\right)$ with $98 \%$ purity from Merck and Fisher Scientific, respectively were used for the $\mathrm{pH}$ adjustment of AnVE. The anaerobically digested vinasse (AnVE) was collected from the final pond in Fermpro Sdn. Bhd, Perlis. The sample was collected at the surface of the final pond and stored at a temperature of $4 \pm 1{ }^{\circ} \mathrm{C}$. It presented dark brown coloration, COD concentration of $7954 \pm 202 \mathrm{mg} / \mathrm{L}$, colour concentration of $42,260 \pm 1070$ $\mathrm{PtCo}$, and $\mathrm{pH}$ value of $8.13 \pm 0.19$.

\section{Photocatalytic Degradation Experiments}

The setup of the photocatalytic reactor is shown in Fig. 1 . The photodegradation experiments were conducted in a 1 L Pyrex beaker and the working volume was $500 \mathrm{~mL}$. An ultraviolet A (UVA) lamp (Philips, 7.7 W, 350-400 nm) was used as the light source in the photoreactor. The beaker was placed $5.0 \mathrm{~cm}$ away from the light source. The photocatalytic tests were carried out with a specific amount of catalyst dispersed in $500 \mathrm{~mL}$ of vinasse (diluted or pre-adjusted $\mathrm{pH}$ ) and they lasted $10 \mathrm{~h}$. Before the light source is switched on, adsorption was carried out for $30 \mathrm{~min}$ by stirring to ensure maximum adsorption-desorption equilibrium. The aeration 
Fig. 1 The set-up of photocatalytic reactor under UVA irradiation

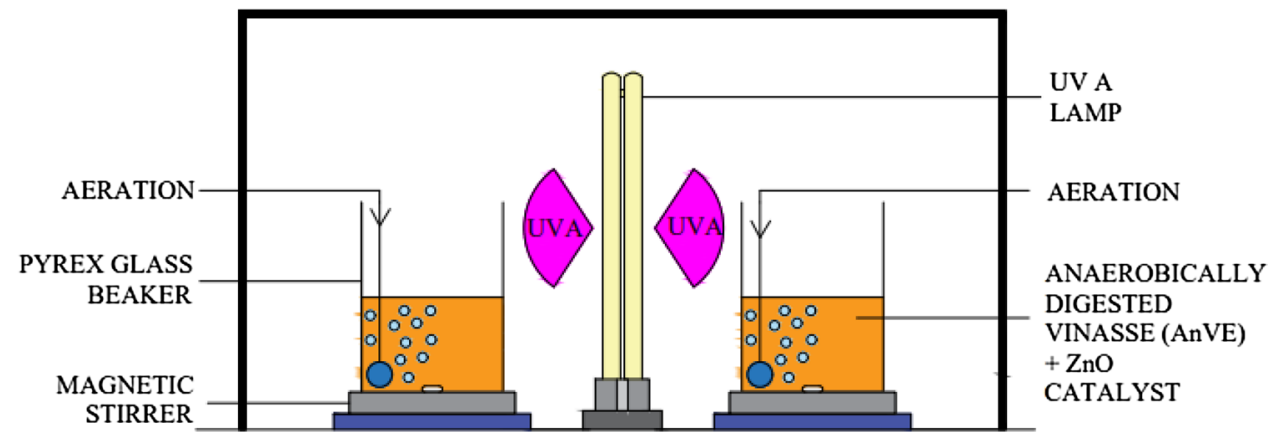

was supplied in the experiment with the room temperature of $25 \pm 2{ }^{\circ} \mathrm{C}$.

\section{Evaluation of the Photodegradation Performance}

The sampling of the AnVE was collected in the reaction times of $1,2,3,4,5,7.5$, and $10 \mathrm{~h}$. The COD concentration $(\mathrm{mg} / \mathrm{L})$ was measured using dichromate reactor digestion method of wastewater analysis, while the colour (PtCo) was measured using a Hach DR/2010 spectrophotometer at the wavelength of $455 \mathrm{~nm}$. Samples were filtered with $0.45 \mu \mathrm{m}$ membrane filters, and the performance of the reactor was determined through COD and colour reduction efficiency using Eq. (1).

Reductionefficiency $(\%)=\left(\frac{C_{0}-C_{1}}{C_{0}}\right) \times 100 \%$,

where $C_{0}$ is the COD concentration $(\mathrm{mg} / \mathrm{L})$ or colour $(\mathrm{PtCo})$ of influent and $C_{1}$ is the COD concentration $(\mathrm{mg} / \mathrm{L})$ or colour (PtCo) of effluent at reaction time $(t)$ in hours.

The material characterization of $\mathrm{ZnO}$ photocatalyst was carried out by X-ray diffraction (XRD) from Bruker (Model: D2 Phaser). X-ray tube is copper $(\mathrm{Cu})$ type (wavelength of $\mathrm{K} \alpha 1=1.5406 \AA$ ) and generated at $30 \mathrm{kV}$ and $10 \mathrm{~mA}$. The scan range of the XRD data was between $20^{\circ}$ and $80^{\circ}(2 \theta)$ with a scan rate of $5^{\circ} / \mathrm{min}$. UV-Vis spectrophotometer (ME-UV1300PC Mesulab, China) was used to conduct the wavelength scan in the samples, while the $\mathrm{pH}$ and temperature were measured using Methrom 826 portable $\mathrm{pH}$ meter. Each experiment was carried out three times to obtain the average results. The effectiveness of photodegradation under various parameters such as initial concentration, $\mathrm{pH}$, and dosage of catalyst on COD and colour reduction efficiencies was determined. Langmuir-Hinshelwood kinetics model was applied to determine the COD and colour reduction rate. It can be simplified to an apparent first-order expression as shown in Eq. (2). $\ln \frac{C_{0}}{C}=k t$,

where the $C_{\mathrm{o}}$ and $C$ represent the initial concentration and concentration at time $t(\mathrm{mg} / \mathrm{L})$, respectively, and $t$ represents the irradiation time, and $k$ is the pseudo-first-order rate constant.

\section{Toxicity Estimation}

The phytotoxicity assessments were carried out in the petri dishes with filter paper, which is simple and cost-friendly. Mung bean ( $V$. radiata) was selected to use in the toxicity test. The phytotoxicity assessments were operated with control (distilled water only), raw AnVE, diluted AnVE, and treated effluent by dispensing $4 \mathrm{~mL}$ of solutions onto filter paper in the $90 \mathrm{~mm}$ diameter petri dishes using the mung bean. Each petri dish was placed with twenty seeds on the filter paper, which was sealed with parafilm to avoid the evaporation process in the petri dish. The seeds were incubated at room temperature, each with three times replicates. The germinated seeds were harvested after 5 days incubation period. The root length and wet weight were measured to determine the toxicity of the wastewater.

\section{Reusability}

The reusability test was carried out through three cumulative cycles of the photocatalytic process at optimized conditions. The supernatant of the AnVE wastewater was drawn after $1 \mathrm{~h}$ of settling process to determine the COD reduction efficiency and decolourization. The remained mixture was dried in the oven for $24 \mathrm{~h}$ to measure the remained $\mathrm{ZnO}$ catalyst in the beaker. The dried $\mathrm{ZnO}$ powder was kept and used for the next cycles. 


\section{Result and Discussion}

\section{Effect of Initial Concentration}

The effect of initial concentration was evaluated in different initial COD concentrations $(250,500,750$, and $1000 \mathrm{mg} / \mathrm{L})$. The photocatalytic tests were carried out with a constant amount of catalyst $(1.0 \mathrm{~g} / \mathrm{L})$ dispersed in $500 \mathrm{~mL}$ of vinasse $(\mathrm{pH})$. The COD reduction efficiency under different initial COD concentrations was shown in Fig. 2a. The highest COD degradation $(42.85 \%)$ was achieved in the initial COD concentration of $250 \mathrm{mg} / \mathrm{L}$. It was found that the COD reduction efficiency kept decreasing when the initial COD concentration increased. The catalyst surface was adsorbed by excessive organic molecules as increasing the COD concentration. Hence, limited hydroxyl was produced due to the less active site of catalyst is available (Mohammadzadeh et al. 2015). Figure $2 \mathrm{~b}$ shows the Langmuir-Hinshelwood (L-H) kinetic model with different COD concentrations. The pseudo-firstorder rate constant was significantly affected by the initial COD concentrations. The highest rate constant $\left(0.0528 \mathrm{~h}^{-1}\right)$ was achieved at the lowest initial COD concentration, which was $250 \mathrm{mg} / \mathrm{L}$ of AnVE. When increased the initial COD

(a)

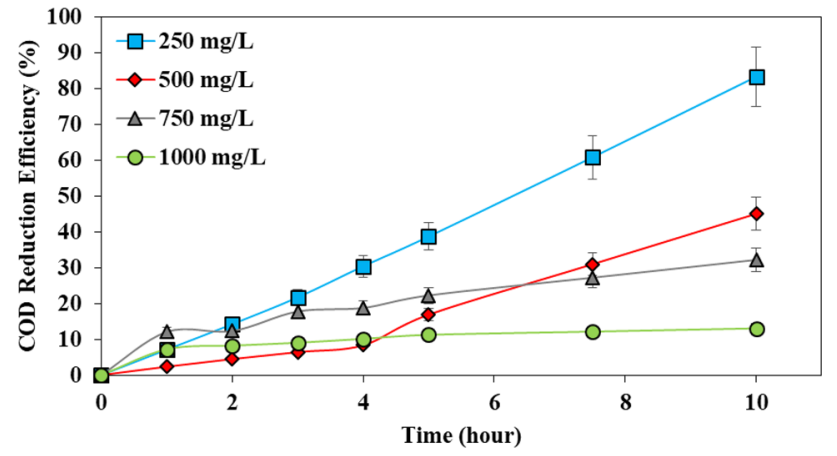

(c)

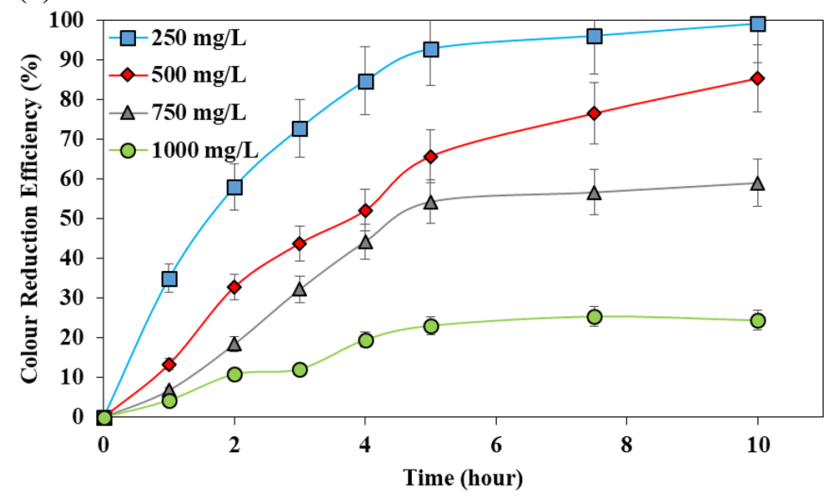

concentration to $1000 \mathrm{mg} / \mathrm{L}$, the rate constant was reduced to $0.0109 \mathrm{~h}^{-1}$. The production of $\cdot \mathrm{OH}$ radical on the catalyst surface was negatively affected by the high initial COD concentration. Since the production of hydroxyl radical remains consistently when the other operational parameters were same, thus the possibility of dye molecules reacting with hydroxyl radical decreases at high initial COD concentration (Kumar et al. 2016).

Figure $2 \mathrm{c}$ demonstrates the decolourization of different COD concentrations. The highest decolourization achieved was $92.79 \%$ for the initial COD concentration of $250 \mathrm{mg} / \mathrm{L}$. The photocatalyst surface can receive more photons when the colour concentration decreased over irradiation time. Thus, the remaining organic molecules can be degraded effectively by more active sites on the catalyst (Ong et al. 2020). Meanwhile, Fig. 2d demonstrated decolourization under different COD concentrations followed pseudofirst-order kinetics. A similar trend was obtained in the decolourization when compared to COD reduction in AnVE. The colour reduction rate constant decreased from 0.2177 to $0.0348 \mathrm{~h}^{-1}$ when the initial COD concentration increased from 250 to $1000 \mathrm{mg} / \mathrm{L}$. The raising of the COD concentration can lead to the increment of the colour concentration, and hence, the number of organic molecules

(b)

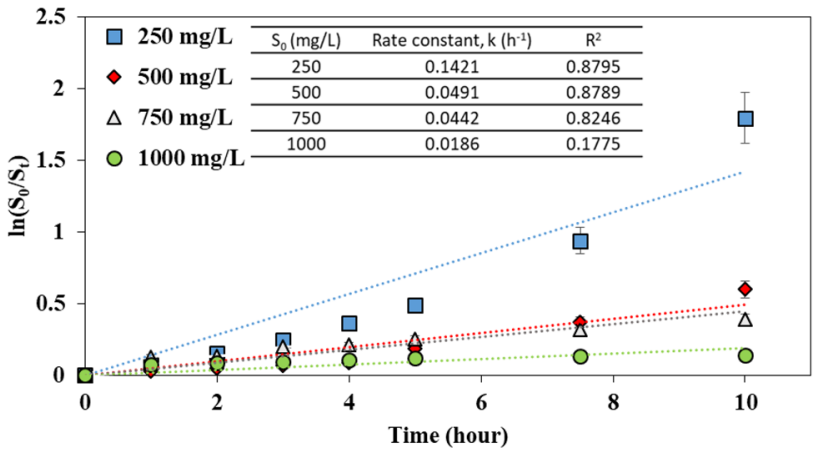

(d)

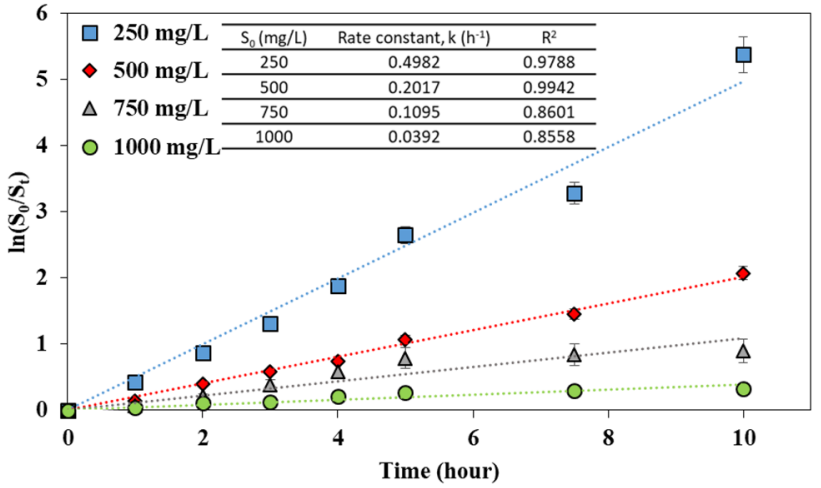

Fig. 2 The performance of a COD reduction efficiency, $\mathbf{b}$ kinetic in terms of COD reduction efficiency, $\mathbf{c}$ colour reduction efficiency, and $\mathbf{d}$ kinetic in terms of colour reduction efficiency under various initial COD concentrations of AnVE with catalyst dosage of $1.0 \mathrm{~g} / \mathrm{L}$ and $\mathrm{pH} 8$ 
react with hydroxyl radical decreases. It was because the increment of colour concentration reduced the path length of photon entering into the solution (Subash et al. 2013a). The kinetic rate constant can be related to the light transmittance of the solution. At higher initial dye concentration, the light transmittance was low, which reduced the light energy to excite the active electrons and holes for photocatalyst (Deng et al. 2018). Similar result was also obtained by Li et al. (2018) that less electron-hole pairs were generated in high initial concentration, and led to inhibition of the hydroxyl formation.

The proposed mechanism of photocatalytic degradation under UV irradiation using $\mathrm{ZnO}$ was investigated. When $\mathrm{ZnO}$ is illuminated by light that photon energy equal or exceeds its band gap energy $\left(h v \geq E_{\mathrm{g}}=3.37 \mathrm{eV}\right)$, the positive holes $\left(\mathrm{h}^{+}{ }_{\mathrm{VB}}\right)$ are produced in the valence band when the electrons $\left(\mathrm{e}^{-}{ }_{\mathrm{CB}}\right)$ from the valence band transfer to the conduction band across the band gap (Eq. 3) (Ong et al. 2019). $\mathrm{h}^{+}{ }_{\mathrm{VB}}$ and $\mathrm{e}^{-}{ }_{\mathrm{CB}}$ are captured by the zinc vacancy near the valence band and the oxygen vacancy near the conduction band, respectively. This can lead to the redox reactions occur at the surface of $\mathrm{ZnO}$ photocatalysts. Hydroxyl radicals $(\cdot \mathrm{OH})$ are generated through the reaction between the holes with either hydroxyl ions $\left(\mathrm{OH}^{-}\right)$ or water $\left(\mathrm{H}_{2} \mathrm{O}\right)($ Eqs. 4,5$)$. The high oxidation potential of holes or hydroxyl radicals could oxidize and degrade the AnVE (Eqs. 6, 7). When the concentration of AnVE increased, the organic molecules adsorbed incident photons before they can reach the catalyst surface, which led to the reduction of degradation rate (Ghaly et al. 2017).

$\mathrm{ZnO}+h v \rightarrow \mathrm{ZnO}\left(\mathrm{e}^{-} \mathrm{CB}+\mathrm{h}^{+} \mathrm{VB}\right)$,

$\mathrm{ZnO}\left(\mathrm{h}^{+} \mathrm{VB}\right)+\mathrm{H}_{2} \mathrm{O} \rightarrow \mathrm{ZnO}+\mathrm{H}^{+}+\cdot \mathrm{OH}$,

$\mathrm{ZnO}\left(\mathrm{h}^{+} \mathrm{VB}\right)+\mathrm{OH}^{-} \rightarrow \mathrm{ZnO}+\cdot \mathrm{OH}$,

$\mathrm{AnVE}+\mathrm{ZnO}\left(\mathrm{h}^{+} \mathrm{VB}\right) \rightarrow \mathrm{ZnO}+\mathrm{AnVE} *($ oxidationof AnVE)

$\mathrm{AnVE}+\cdot \mathrm{OH} \rightarrow \mathrm{AnVE}^{*-}($ degradationof AnVE).

However, excess electrons remain in the wastewater because the reaction of the electrons is slow when compared to the holes on the catalyst surface. Thus, the addition of oxygen molecules is necessary through the aeration to prevent the recombination of electrons with holes. The superoxide radical anions $\left(\cdot \mathrm{O}_{2}^{-}\right)$and hydrogen peroxide $\left(\mathrm{H}_{2} \mathrm{O}_{2}\right)$ as strong oxidants are formed when the electrons reduce with the oxygen molecules (Eqs. 8, 9). $\cdot \mathrm{O}_{2}^{-}$ could be implicated in the generation of hydroxyl radical through the reaction with $\mathrm{H}^{+}$(Eq. 10) or $\mathrm{H}_{2} \mathrm{O}$ molecules
(Eq. 11). Hydrogen superoxide in Eq. (10) could capture the electrons and further delay the recombination process. Besides that, the generated $\mathrm{H}_{2} \mathrm{O}_{2}$ could further react with the electron to produce hydroxyl radicals and hydroxyl ions (Eq. 12). $\cdot \mathrm{O}_{2}^{-}$could oxidize and degrade the AnVE (Eq. 13), while the reduction of AnVE also is included in the removal mechanisms by the electron in the conduction band (Eq. 14):

$\mathrm{ZnO}\left(\mathrm{e}^{-} \mathrm{CB}\right)+\mathrm{O}_{2} \rightarrow \cdot \mathrm{O}_{2}^{-}$,

$\mathrm{O}_{2}+2 \mathrm{ZnO}\left(\mathrm{e}^{-} \mathrm{CB}\right)+2 \mathrm{H}^{+} \rightarrow \mathrm{H}_{2} \mathrm{O}_{2}$,

$\cdot \mathrm{O}_{2}^{-}+\mathrm{H}^{+} \rightarrow \mathrm{HOO} \cdot \rightarrow \mathrm{HO} \cdot$

$\cdot \mathrm{O}_{2}^{-}+\mathrm{H}_{2} \mathrm{O} \rightarrow \cdot \mathrm{OH}+\mathrm{OH}^{-}$

$\mathrm{H}_{2} \mathrm{O}_{2}+\mathrm{ZnO}\left(\mathrm{e}^{-} \mathrm{CB}\right) \rightarrow \cdot \mathrm{OH}+\mathrm{OH}^{-}$

$\cdot \mathrm{O}_{2}^{-}+\mathrm{AnVE} \rightarrow$ AnVE*(oxidationof AnVE)

$\mathrm{AnVE}+\mathrm{ZnO}\left(\mathrm{e}^{-} \mathrm{CB}\right) \rightarrow \mathrm{AnVE} *($ reductionof AnVE).

\section{Effect of $\mathrm{pH}$}

The effect of $\mathrm{pH}$ was significant to be illuminated in the study on photocatalytic degradation, as different $\mathrm{pH}$ values can contribute to various effects in the wastewater treatment. In this study, the $\mathrm{pH}$ value was fixed in the range of $\mathrm{pH} 3-\mathrm{pH}$ 12 with COD concentration of $250 \mathrm{mg} / \mathrm{L}$ and catalyst dosage of $1.0 \mathrm{~g} / \mathrm{L}$ to evaluate the influence of $\mathrm{pH}$ on the treatment performances of photocatalytic reactor. The COD reduction efficiency of different $\mathrm{pH}$ in the photocatalytic reactor was shown in Fig. 3a. The increment of $\mathrm{pH}$ from 3 to 10 led to an increase in the COD degradation from 17.42 to $69.26 \%$. The ability of photocatalytic process to accelerate hydroxyl radical formation at alkaline conditions improved the COD reduction efficiency (Ranjbari and Mokhtarani 2018). The results can be related to the highest rate constant $\left(k=0.1028 \mathrm{~h}^{-1}\right)$ achieved at $\mathrm{pH} 10$, as shown in Fig. 3b. The electrostatic interactions of catalyst are occurred more rapidly in the alkaline solution (Sarafraz et al. 2020). In addition, the hydroxyl radicals were produced more rapidly at high $\mathrm{pH}$ condition, as indicated in Eq. (5). However, the COD reduction efficiency reduced to $28.29 \%$ when the $\mathrm{pH}$ value further increased to 12 . The complexes such as $\mathrm{Zn}(\mathrm{OH})_{4}{ }^{2-}$ can be formed in the dissolution of $\mathrm{ZnO}$ under high alkaline condition (Eq. (15)). 
(a)

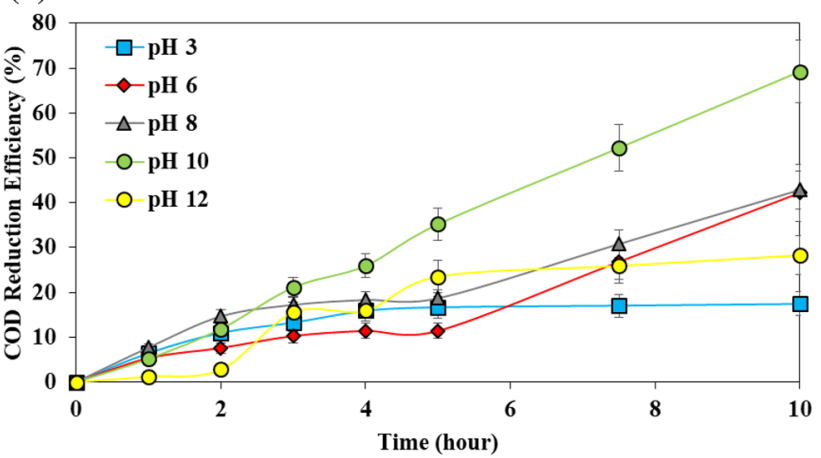

(c)

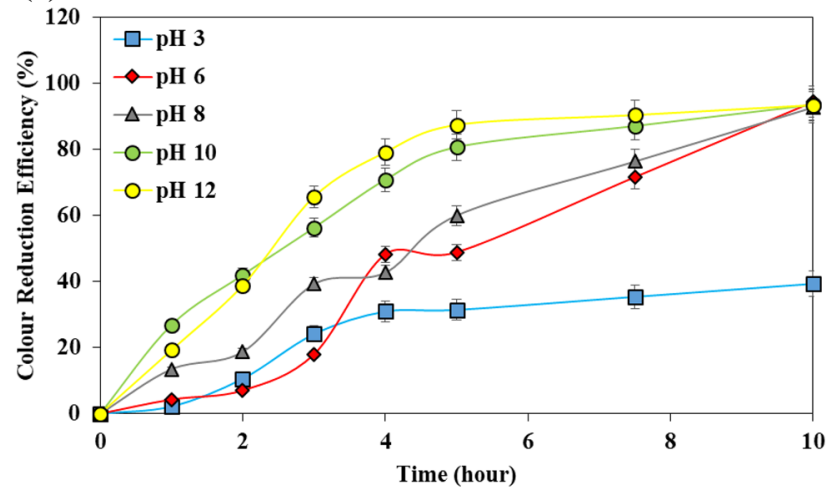

Fig. 3 The performance of a COD reduction efficiency, $\mathbf{b}$ kinetic in terms of COD reduction efficiency, $\mathbf{c}$ colour reduction efficiency, and d kinetic in terms of colour reduction efficiency under various $\mathrm{pH}$

$\mathrm{ZnO}+2 \mathrm{OH}^{-}+\mathrm{H}_{2} \mathrm{O} \rightarrow \mathrm{Zn}(\mathrm{OH})_{4}^{2-}$.

The anion would be repelled by the negatively charged $\mathrm{ZnO}$ and impedes the oxidation process at the photocatalyst (Khalik et al. 2017). The $\mathrm{ZnO}$ surface was absorbed by $\mathrm{OH}^{-}$and $\mathrm{h}^{+}$at a very alkaline $\mathrm{pH}$, which could form the surface hydroxyl radicals (\% OHs). The surface hydroxyl radicals were hardly desorbed and reduced the removal efficiency (Chen et al. 2020).

The decolourization of different $\mathrm{pH}$ in the photocatalytic reactor was shown in Fig. 3c. The decolourization increased from $\mathrm{pH} 3$ to $\mathrm{pH} 10$ (39.36-93.59\%) which was similar to the trend of COD removal. The enhancement of decolourization can be illustrated as the production of oxygen radicals from the Lewis acid positions created the -OH radicals in the presence of water under the alkaline condition (Alamgholiloo et al. 2019). When the solution further increased to $\mathrm{pH} \mathrm{12,} \mathrm{the} \mathrm{decolourization} \mathrm{rate} \mathrm{was}$ still maintained at $93.46 \%$. The results revealed that at a very high $\mathrm{pH}$ value, the COD removal was affected negatively but a high decolourization rate was maintained. As illustrated in Fig. 3d, the pseudo-first-order rate constant achieved the highest at $\mathrm{pH} 12\left(k=0.3127 \mathrm{~h}^{-1}\right)$ instead of (b)

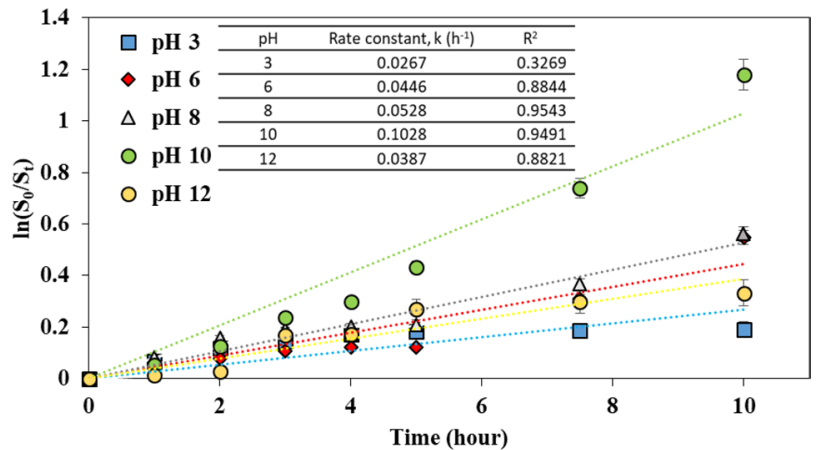

(d)

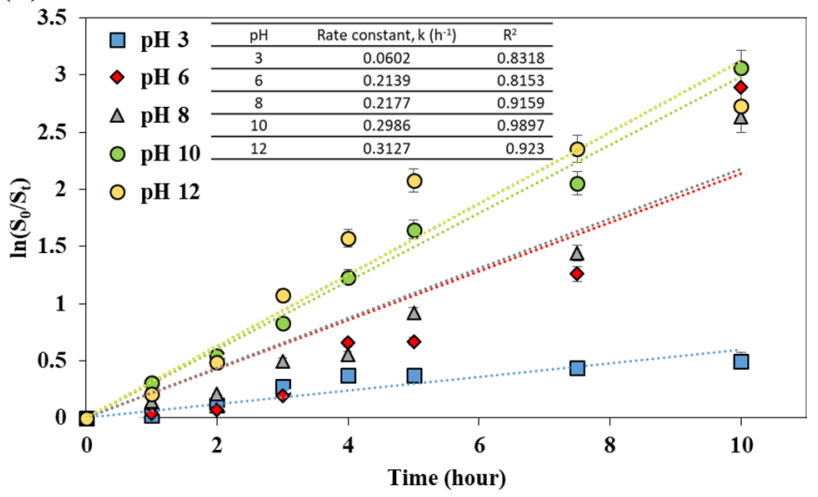

values of AnVE with COD concentration of $250 \mathrm{mg} / \mathrm{L}$ and catalyst dosage of $1.0 \mathrm{~g} / \mathrm{L}$

pH $10\left(k=0.2986 \mathrm{~h}^{-1}\right)$. It is believed that at alkaline $\mathrm{pH}$ conditions, the indirect reaction between organic molecules and $\cdot \mathrm{OH}$ radicals improves the treatment efficiency (Asgari et al. 2021). The lowest COD removal and decolourization efficiency of AnVE at low $\mathrm{pH}(\mathrm{pH} 3)$ might be ascribed to the reaction between $\mathrm{ZnO}$ and the acids to form $\mathrm{Zn}^{2+}$ (Eq. 16) (Wu 2008). Thus, the photocatalytic properties of $\mathrm{ZnO}$ were limited under acidic conditions (Subash et al. 2013b).

$\mathrm{ZnO}+2 \mathrm{H}^{+} \rightarrow \mathrm{Zn}^{2+}+\mathrm{H}_{2} \mathrm{O}$.

\section{Effect of Dosage of Catalyst}

\section{Performance of Photocatalytic Reactor Under Various Catalyst Dosage}

The photocatalytic degradation was carried out under COD concentration of $250 \mathrm{mg} / \mathrm{L}$ and optimum $\mathrm{pH} 10$ with different catalyst dosages from 0.5 to $2.0 \mathrm{~g} / \mathrm{L}$. The catalyst dosage was known as having a significant effect on the COD reduction efficiency and decolourization of photocatalytic 
(a)

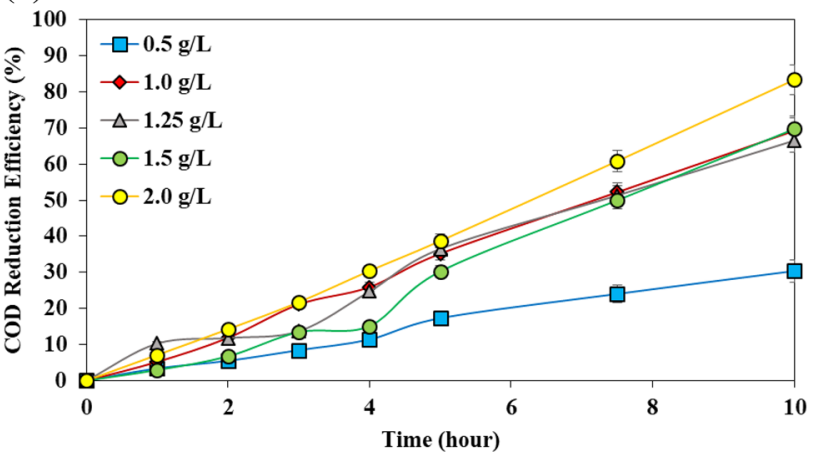

(c)

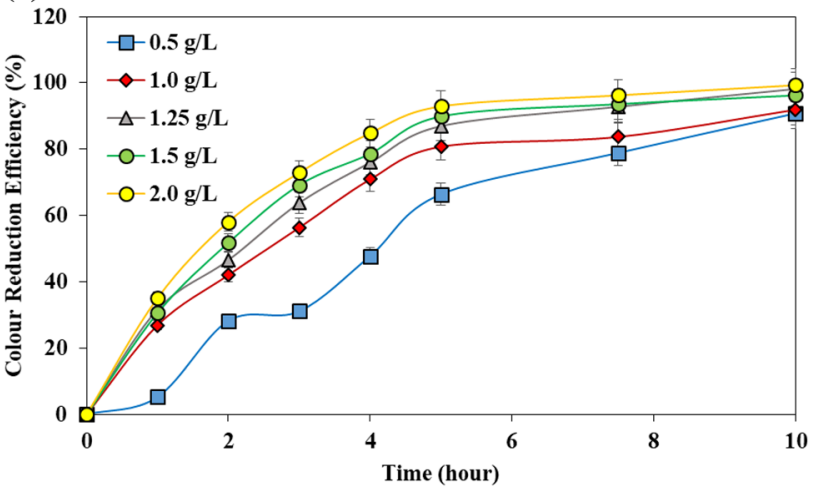

(b)

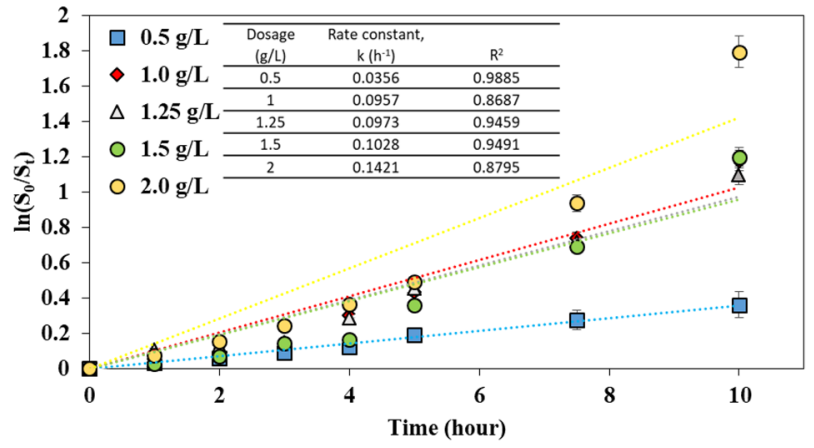

(d)

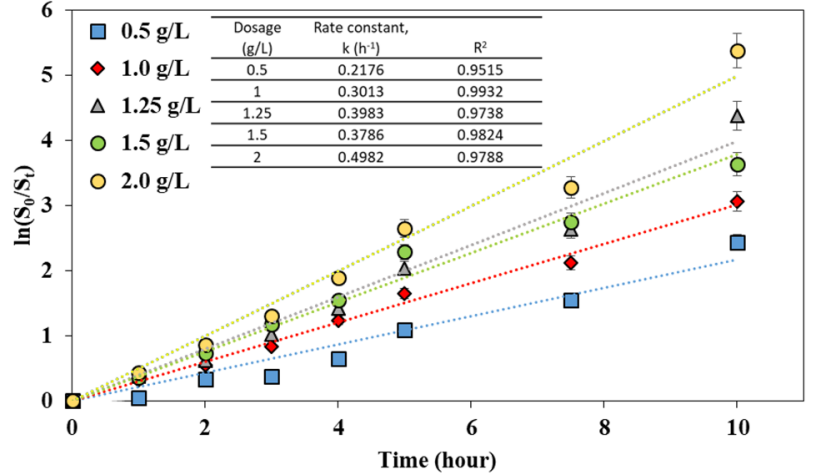

Fig. 4 The performance of a COD reduction efficiency, $\mathbf{b}$ kinetic in terms of COD reduction efficiency, $\mathbf{c}$ colour reduction efficiency, and $\mathbf{d}$ kinetic in terms of colour reduction efficiency under various initial catalyst dosages of AnVE with COD concentration of $250 \mathrm{mg} / \mathrm{L}$ and $\mathrm{pH} 10$

degradation. The effectiveness of photocatalytic degradation in terms of COD reduction increased from catalyst dosage of $0.5 \mathrm{~g} / \mathrm{L}(30.38 \%)$ to $2.0 \mathrm{~g} / \mathrm{L}(83.40 \%)$ as shown in Fig. $4 \mathrm{a}$. When the catalyst dosage increased, there were many active sites generated in the catalyst. It provided a larger adsorption area and more active radicals for the removal of COD (Ahmed et al. 2010). The rate constant achieved the highest $\left(k=0.1421 \mathrm{~h}^{-1}\right)$ at a catalyst dosage of $2.0 \mathrm{~g} / \mathrm{L}$, as illustrated in Fig. 4b. The increment of catalyst dosage can promote the production of active radicals from a larger surface area (Asgari et al. 2021). Thus, the larger surface area of the zinc oxide was excited by the abundant and active radicals when the catalyst dosage was increased, which ultimately improve the treatment efficiency (Chen et al. 2011).

Figure $4 \mathrm{c}$ indicates that the decolourization increased from catalyst dosage of $0.5 \mathrm{~g} / \mathrm{L}(90.81 \%)$ to $2.0 \mathrm{~g} / \mathrm{L}$ $(99.29 \%)$. A similar result was obtained from Fig. $4 d$ as the increment of catalyst dosage improved the rate constant from $0.2176(0.5 \mathrm{~g} / \mathrm{L})$ to $0.4982 \mathrm{~h}^{-1}(2.0 \mathrm{~g} / \mathrm{L})$. The catalyst dosage was usually related to the nature of photocatalyst and the irradiation light source (Rao et al. 2009). A sufficient amount of $\mathrm{ZnO}$ catalyst provided in the photocatalytic degradation can maximize the degradation effect with the appropriate light irradiation. However, excessive catalyst dosage

Table 1 COD reduction efficiency, colour reduction efficiency, and rate constant before and after optimization under various COD concentration

\begin{tabular}{|c|c|c|c|c|c|c|c|c|}
\hline \multirow{2}{*}{$\begin{array}{l}\text { Initial COD } \\
\text { concentration } \\
(\mathrm{mg} / \mathrm{L})\end{array}$} & \multicolumn{4}{|c|}{ Before optimization } & \multicolumn{4}{|c|}{ After optimization } \\
\hline & $\begin{array}{l}\mathrm{COD} \\
\text { reduction } \\
(\%)\end{array}$ & $\begin{array}{l}\text { Rate constant for } \\
\text { COD reduction } \\
\left(\mathrm{h}^{-1}\right)\end{array}$ & $\begin{array}{l}\text { Colour } \\
\text { reduction } \\
(\%)\end{array}$ & $\begin{array}{l}\text { Rate constant for } \\
\text { colour reduction } \\
\left(\mathrm{h}^{-1}\right)\end{array}$ & $\begin{array}{l}\mathrm{COD} \\
\text { reduction } \\
(\%)\end{array}$ & $\begin{array}{l}\text { Rate constant for } \\
\text { COD reduction } \\
\left(\mathrm{h}^{-1}\right)\end{array}$ & $\begin{array}{l}\text { Colour } \\
\text { reduction } \\
(\%)\end{array}$ & $\begin{array}{l}\text { Rate constant for } \\
\text { colour reduction } \\
\left(\mathrm{h}^{-1}\right)\end{array}$ \\
\hline 250 & 42.86 & 0.0528 & 92.79 & 0.2177 & 83.40 & 0.1421 & 99.29 & 0.4982 \\
\hline 500 & 22.78 & 0.0309 & 85.14 & 0.1287 & 45.09 & 0.0491 & 85.48 & 0.2017 \\
\hline 750 & 12.59 & 0.0177 & 41.69 & 0.0509 & 32.21 & 0.0442 & 59.09 & 0.1095 \\
\hline 1000 & 8.92 & 0.0109 & 24.43 & 0.0348 & 13.05 & 0.0186 & 25.24 & 0.0392 \\
\hline
\end{tabular}


can generate adverse effects to photocatalytic degradation due to the large amount of particle aggregation accumulated in the solution, which reduced the surface active sites of catalyst (Rajamanickam and Shanthi 2014). In other words, when the catalyst dosage beyond the limit, the turbidity of the dye solution increased and prevented the transmission of light irradiation to the solution, which led to the light scattering effect (Daneshvar et al. 2007).

The effectiveness of photocatalytic degradation in terms of COD reduction efficiency and decolourization before and after the optimization of $\mathrm{pH}$ and catalyst dosage was indicated in Table 1. The result showed that at the initial COD concentration of $250 \mathrm{mg} / \mathrm{L}$, the COD removal increased from 42.86 to $83.40 \%$ while the decolourization increased from 92.79 to $99.29 \%$ in the optimum conditions. The COD reduction efficiency for the initial concentration of $500 \mathrm{mg} / \mathrm{L}$ showed a great enhancement from 22.78 to $45.09 \%$, but the decolourization remained consistent at $85.48 \%$. At the initial COD concentration of $750 \mathrm{mg} / \mathrm{L}$, a significant improvement was obtained after optimization which the COD reduction efficiency increased from 12.59 to $32.21 \%$ and the decolourization increased from 41.69 to $59.09 \%$. However, it indicated a minor enhancement in terms of COD and colour removal at an initial COD concentration of $1000 \mathrm{mg} / \mathrm{L}$. The enhancement of performance after optimization can be proved through the increment of rate constant in Table 2. The overall kinetic rate constant in various initial COD concentration showed a great improvement except in the initial COD concentration of $1000 \mathrm{mg} / \mathrm{L}$. It can be explained by the intensive dark colour that the UV light hard to penetrate through the AnVE for the production of hydroxyl radicals.

\section{Photocatalyst Characterization}

The material characterization of purchased $\mathrm{ZnO}$ powder was analyzed through XRD analysis. The XRD patterns of the $\mathrm{ZnO}$ photocatalyst are presented in Fig. 5. The diffraction peaks located at $31.90^{\circ}, 34.55^{\circ}, 36.37^{\circ}, 47.65^{\circ}, 56.70^{\circ}$, $62.95^{\circ}, 66.47^{\circ}, 68.05^{\circ}, 69.18^{\circ}, 72.65^{\circ}$, and $77.24^{\circ}$. Thus, it could be indexed as hexagonal wurtzite structure of $\mathrm{ZnO}$

Table 2 COD reduction efficiency and colour reduction efficiency under various operational conditions

\begin{tabular}{llcc}
\hline No & Operational conditions & $\begin{array}{l}\text { COD reduction } \\
(\%)\end{array}$ & $\begin{array}{l}\text { Colour } \\
\text { reduction } \\
(\%)\end{array}$ \\
\hline 1 & ZnO only & - & - \\
2 & ZnO+ aeration & - & - \\
3 & UV only & 5.7 & 2.9 \\
4 & UV + aeration & 9.3 & 9.2 \\
5 & ZnO+ UV & 35.7 & 91.4 \\
6 & ZnO+UV + aeration & 38.7 & 92.9 \\
\hline
\end{tabular}

(ICSD 98-006-5188). No impurity was detected, which indicated the presence of $\mathrm{ZnO}$ only in the photocatalysts.

\section{UV-Vis Spectra Analysis}

The result of UV-Vis absorption spectra from 200 to $600 \mathrm{~nm}$ at various irradiation times was shown in Fig. 6 under the optimum conditions of $250 \mathrm{mg} / \mathrm{L}$ COD concentration, $\mathrm{pH}$ 10 , and $2.0 \mathrm{~g} / \mathrm{L}$ of catalyst dosage. The result shows that the absorbance bands reduced over the irradiation time in photocatalytic degradation in $10 \mathrm{~h}$ of irradiation. Hence, a peak $\left(\lambda_{\max }\right)$ observed in the UV-vis spectra of $203 \mathrm{~nm}$ could relate to the presence of ethanol in the vinasse. The absorbance at $203 \mathrm{~nm}$ decreased from 1.922 to 0.510 after $10 \mathrm{~h}$ of irradiation time. Besides that, a $\lambda_{\max }(280 \mathrm{~nm})$ has been related to the presence of organic compounds and the compounds were completely degraded after the photocatalytic process (Arreola et al. 2020). This result can be proved through the mineralization of total organic carbon (TOC). The average TOC was obtained based on the Eqs. (17) and (18) in the

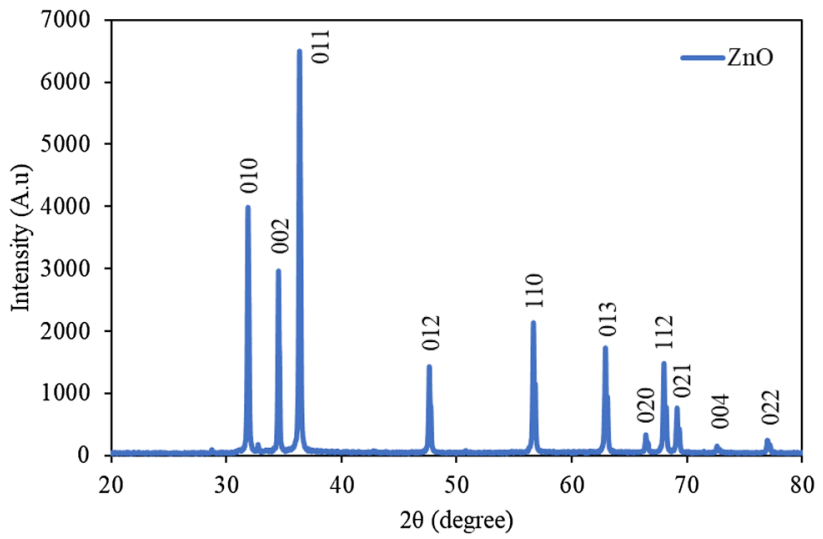

Fig. 5 XRD patterns of $\mathrm{ZnO}$ photocatalyst

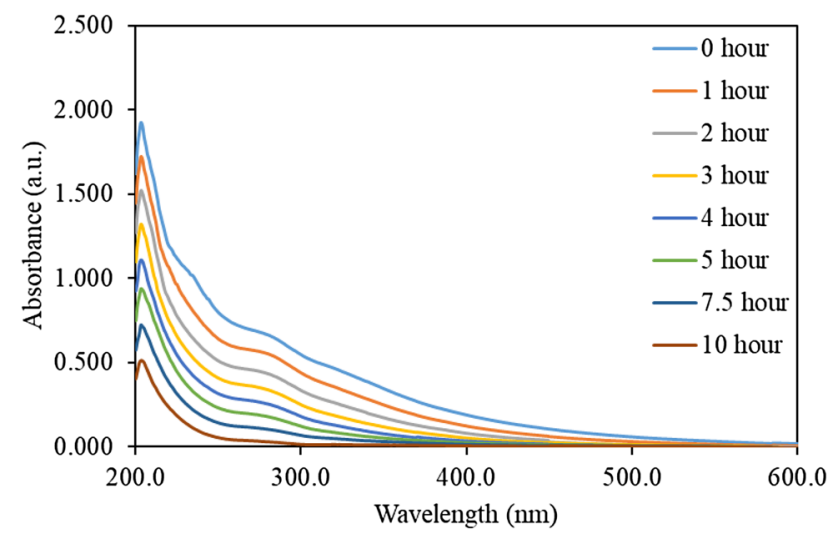

Fig. 6 UV-vis absorption spectra of AnVE under the optimum conditions of $250 \mathrm{mg} / \mathrm{L}$ COD concentration, $\mathrm{pH} 10$ and $2.0 \mathrm{~g} / \mathrm{L}$ of catalyst dosage 
study of Dubber and Gray (2010). The mineralization of TOC achieved $93.8 \%$, which was similar to the result in the UV-vis spectra of $280 \mathrm{~nm}(95.8 \%)$. The results revealed that the complete removal of organic compounds was achieved after the photocatalytic process. The majority of organic carbon was degraded when compared to inorganic carbon, since the COD reduction was only $83.40 \%$. In this study, the absorbance reduction achieved $94.98 \%$ at $10 \mathrm{~h}$ of irradiation time when considering the wavelength of $270 \mathrm{~nm}$ as the reference point. Compared to this study, the photocatalytic degradation of pre-treated vinasse (coagulation/flocculation) only showed $67.1 \%$ of reduction in absorbance at $270 \mathrm{~nm}$ (Padilha et al. 2013).

$$
\begin{aligned}
& \mathrm{TOC}=\frac{\mathrm{COD}-49.2}{3}, \\
& \mathrm{TOC}=\frac{\mathrm{COD}-7.25}{2.99} .
\end{aligned}
$$

\section{Effect of operational conditions}

In the present study, the photocatalytic reactor was carried out with various operational conditions ( $\mathrm{ZnO}$ only, $\mathrm{ZnO}+$ aeration, $\mathrm{UV}$ only, $\mathrm{UV}+$ aeration, $\mathrm{ZnO}+\mathrm{UV}$, $\mathrm{ZnO}+\mathrm{UV}+$ aeration) under the optimum condition $(250 \mathrm{mg} / \mathrm{L}$ of initial COD concentration, $\mathrm{pH} 10$ and $2.0 \mathrm{~g} / \mathrm{L}$ ). The impact of every parameter independently or in combination were investigated and the results were shown in Table 2. The solution was stirred for $30 \mathrm{~min}$ with the catalyst in the dark environment before starting the photocatalytic process, and it showed a negligible adsorption effect. Besides that, the results indicated that the presence of $\mathrm{ZnO}$ only and $\mathrm{ZnO}+$ aeration had no effect on the COD reduction efficiency and decolourization of AnVE since both reduction efficiency was considered negligible in the listed conditions. It can be attributed to the absence of UV light and thus the generation of hydroxyl radicals was adversely affected. According to Sheikhmohammadi et al. (2020), the removal of pollutants using $\mathrm{ZnO}$ catalyst through the adsorption was not significant. The photolysis experiment under the optimum conditions (UV only) obtained $5.7 \%$ of COD reduction efficiency and $2.9 \%$ of decolourization. Furthermore, the addition of aeration in the photolysis experiment (UV + aeration) obtained 9.3\% of COD reduction efficiency and $9.2 \%$ of decolourization, which was better than UV only.

On the other hand, the operational conditions of $\mathrm{ZnO}+\mathrm{UV}$ and $\mathrm{ZnO}+\mathrm{UV}+$ aeration showed excellent $\mathrm{COD}$ reduction efficiency (35.7\% and $38.7 \%$ ) and decolourization (91.4\% and $92.9 \%$ ), respectively in $5 \mathrm{~h}$ of UV irradiation. The photocatalytic process with the existence of UV and photocatalyst led to redox reactions, thus the electron-hole pairs were created and produced hydroxyl radicals (Asgari et al. 2021). These findings indicated that the production of hydroxyl radicals can only be successful with the presence of UV radiation and photocatalyst (Moussavi et al. 2014). The addition of aeration in the photocatalytic degradation showed a positive effect on both COD and colour removal because oxygen molecules as electron acceptors formed superoxide radical anions with existing electrons to remove the organic molecules in AnVE (Eq. 8).

\section{Toxicity Assessment}

A higher concentration of molasses-based wastewater could cause phytotoxic effect on the plants because it consists of multiple types of constituents. However, the development and growth of plants were enhanced by the treated molassesbased wastewater, which in lower concentration (Pandey and Soni 1994). The root length and fresh weight of the mung bean $(V$. radiata) were shown in Fig. 7 . The root length and fresh weight were achieved lowest in the raw AnVE, which indicated that raw AnVE consisted of the highest toxicity among all the wastewater. The result showed that the growth of root was significantly affected in higher wastewater concentrations. The reduction of the shoot and root length could occur when the exposure of root in a higher concentration of effluent affects the cell growth (Kannan and Upreti 2008). After the treatment through photocatalytic degradation, the effluent showed lower toxicity when compared to the influent. The toxicity reduction can be observed from UV-Vis absorption spectra in Fig. 6. The organic compounds existed in the effluent were gradually reduced after the treatment. Santal et al. (2011) observed that treated effluent was not inhibited the growth of seeds compared to the influent since the toxicity of effluent decreases after treatment (Santal et al. 2011). The lower toxicity in effluent also can be justified through the higher fresh weight of the mung bean obtained using effluent when compared to influent. The effects on

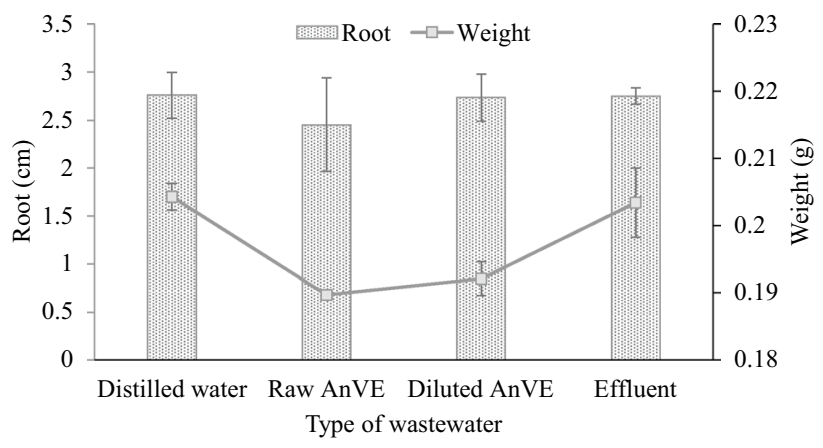

Fig. 7 The root length and wet weight of mug bean at different types of wastewaters 


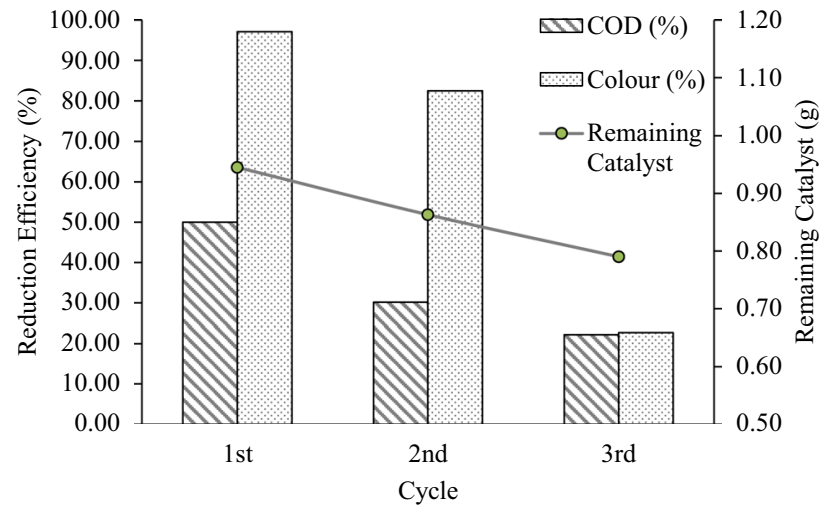

Fig. 8 Reusability test for the photocatalytic degradation of AnVE by using $\mathrm{ZnO}$ photocatalyst

fresh biomass implied the seedling's water uptake and transport which is an important mechanism for their stimulation (Sun et al. 2020). The control (distilled water) indicated that a similar result was obtained when compared to treated AnVE (effluent) and thus it revealed that the water quality of treated effluent was approximately similar to distilled water.

\section{Reusability}

The reusability of $\mathrm{ZnO}$ was determined in terms of COD reduction efficiency, decolourization, and the remained catalyst for three cycles at optimized conditions (Fig. 8). Approximately $7 \%$ of catalyst was lost in each cycle, which revealed that $93 \%$ of catalyst recovery was achieved. However, the COD reduction efficiency decreased from $50.0 \%$ to $22.2 \%$ while the decolorization reduced from 97.1 to $22.7 \%$ after three cycles of operation. The reduction of COD reduction efficiency and decolourization can be related to the mass loss during catalyst recovery and the depletion of the active sites in the catalyst with the adsorption of organic molecules in each cycle (Lops et al. 2019). Thus, the reusability of $\mathrm{ZnO}$ in this study can become a future scope to explore the reuse potential through modification of the catalyst surface.

\section{Comparison on the Effectiveness of Photodegradation of AnVE in COD and Colour Removal with Past Studies}

The comparison of the photocatalytic degradation performance of vinasse/molasses-based wastewater was conducted between past reported studies and this study with different types of photocatalysts. The heterogeneous photocatalysis in the study of Poblete et al. (2020) achieved COD (58\%) and colour (40\%) removal in treating pisco vinasse using $\mathrm{TiO}_{2}$ as photocatalyst. In the study of Apollo et al. (2013), UV photodegradation achieved colour removal of $54 \%$ and $69 \%$ for the real distillery effluent and raw molasses, respectively, with a COD reduction of $<20 \%$. The study by Navgire et al. (2012) also achieved effective photodegradation of the molasses in removing COD (90\%) and colour (70\%) using $\mathrm{MoO}_{3}-\mathrm{TiO}_{2}$ nanocrystalline composite catalyst. Indium yttrium oxide $\left(\mathrm{InYO}_{3}\right)$ photocatalyst was prepared and calcined at $700{ }^{\circ} \mathrm{C}$ in the study of Qin et al. (2011), and it showed higher photocatalytic activity in the photodegradation of molasses fermentation wastewater (93\% COD removal and $98 \%$ decolorization). Hence, the calcination of $\mathrm{ZnO}$ at a high temperature was recommended and could be applied to improve photocatalytic activity. To the best of the authors' knowledge, there was rarely reported regarding the photocatalytic process of molasses-based wastewater through $\mathrm{ZnO}$ photocatalyst. This study achieved excellent COD reduction efficiency $(83.40 \%)$ and decolourization (99\%) in the photocatalytic treatment of vinasse using $\mathrm{ZnO}$. It showed that $\mathrm{ZnO}$ had great potential in the treatment of molasses-based wastewater and the performance of the $\mathrm{ZnO}$ can be enhanced through the modification in terms of dye sensitization, metal-ion doping, and composite photocatalysts (Long et al. 2020). Thus, $\mathrm{ZnO}$ can be modified to composite catalyst with another semiconductor material to enhance the photocatalytic activity, accelerate the transfer of photogenerated electron holes, and prolong the lifetime of the photogenerated holes (Nasir et al. 2020). Besides that, the photocatalytic degradation in the treatment of distillery effluent and vinasse under solar radiation revealed the potential of the photocatalytic process in the treatment of molasses-based wastewater using $\mathrm{ZnO}$ under sunlight could be applied in further studies (Santana and Fernandes Machado 2008; Vineetha et al. 2013).

\section{Conclusion}

Photocatalytic degradation is an advanced oxidation process that utilizes photocatalyst to treat wastewater in the presence of UV light and can be deemed to be eco-friendly. Sugarcane vinasse is a dark brown colour and high organic wastewater, which was treated using photocatalytic degradation under various parameters such as initial concentration, $\mathrm{pH}$ value and catalyst dosage. The results revealed that the COD reduction efficiency and decolourization kept decreasing when the initial COD concentration increased. Furthermore, photocatalytic degradation achieved the most outstanding performance at the alkaline condition ( $\mathrm{pH} 10)$, which can be explained by the rapid electrostatic interactions of catalysts in the alkaline condition. When the catalyst dosage increased from 0.5 to $2.0 \mathrm{~g} / \mathrm{L}$, the decolorization and COD reduction efficiency also increased due to larger active sites generated in the solution. The phytotoxicity assessment using mung bean ( $V$. radiata) indicated that the toxicity of AnVE 
solution could be reduced effectively through the photocatalytic degradation process. Besides that, the catalyst recovery achieved $93 \%$ in the reusability test, but the COD reduction efficiency and decolourization were reduced in every cycle. Thus, it can be concluded that the effective COD reduction efficiency and decolourization of AnVE were achieved using photocatalytic degradation under the optimum conditions.

Acknowledgements The authors would like to express their sincere gratitude to Faculty of Civil Engineering Technology Universiti Malaysia Perlis (UniMAP) and Fermpro Industries.

Author contributions Conceptualization: W-CK; methodology: W-CK; formal analysis and investigation: W-CK, AC; writing — original draft preparation: W-CK; writing - review and editing: Y-SW; resources: Y-SW, S-AO, S-TS, K-ME; supervision: Y-SW, S-AO, NAL.

Funding No funding was received to assist with the preparation of this manuscript.

Availability of data and materials All data generated or analysed during this study are included in this published article.

\section{Declarations}

Conflict of interest The authors declare that they have no competing interests.

Ethics approval and consent to participate Not applicable.

Consent for publication Not applicable.

\section{References}

Ahmed S, Rasul MG, Martens WN et al (2010) Heterogeneous photocatalytic degradation of phenols in wastewater: a review on current status and developments. Desalination 261:3-18. https://doi. org/10.1016/j.desal.2010.04.062

Alamgholiloo H, Zhang S, Ahadi A et al (2019) Synthesis of bimetallic 4-PySI-Pd@Cu(BDC) via open metal site Cu-MOF: effect of metal and support of $\mathrm{Pd} @ \mathrm{Cu}-\mathrm{MOF}$ in $\mathrm{H} 2$ generation from formic acid. Mol Catal 467:30-37. https://doi.org/10.1016/j.mcat.2019. 01.031

Apollo S, Onyango MS, Ochieng A (2013) An integrated anaerobic digestion and UV photocatalytic treatment of distillery wastewater. J Hazard Mater 261:435-442. https://doi.org/10.1016/j.jhazm at.2013.06.058

Arreola AR, Tizapa MS, Zurita F et al (2020) Treatment of tequila vinasse and elimination of phenol by coagulation-flocculation process coupled with heterogeneous photocatalysis using titanium dioxide nanoparticles. Environ Technol (united Kingdom) 41:1023-1033. https://doi.org/10.1080/09593330.2018.1518994

Asgari E, Sheikhmohammadi A, Nourmoradi H et al (2021) Degradation of ciprofloxacin by photocatalytic ozonation process under irradiation with UVA: comparative study, performance and mechanism. Process Saf Environ Prot 147:356-366. https://doi.org/10. 1016/j.psep.2020.09.041

Chen C, Liu J, Liu P, Yu B (2011) Investigation of photocatalytic degradation of methyl orange by using nano-sized $\mathrm{ZnO}$ catalysts. Adv Chem Eng Sci 01:9-14. https://doi.org/10.4236/aces.2011.11002
Chen X, Yao J, Xia B et al (2020) Influence of pH and DO on the ofloxacin degradation in water by UVA-LED/TiO2 nanotube arrays photocatalytic fuel cell: mechanism, ROSs contribution and power generation. J Hazard Mater 383:1-11. https://doi.org/ 10.1016/j.jhazmat.2019.121220

Daneshvar N, Rasoulifard MH, Khataee AR, Hosseinzadeh F (2007) Removal of C.I. acid orange 7 from aqueous solution by UV irradiation in the presence of $\mathrm{ZnO}$ nanopowder. J Hazard Mater 143:95-101. https://doi.org/10.1016/j.jhazmat.2006.08.072

daSilva JJ, daSilva BF, Stradiotto NR et al (2021) Identification of organic contaminants in vinasse and in soil and groundwater from fertigated sugarcane crop areas using target and suspect screening strategies. Sci Total Environ. https://doi.org/10.1016/j.scitotenv. 2020.143237

Deng B, Fu S, Zhang Y et al (2018) Simultaneous pollutant degradation and power generation in visible-light responsive photocatalytic fuel cell with an Ag-TiO2 loaded photoanode. Nano-Struct Nano-Obj 15:167-172. https://doi.org/10.1016/j.nanoso.2017.09. 011

Dubber D, Gray NF (2010) Replacement of chemical oxygen demand (COD) with total organic carbon (TOC) for monitoring wastewater treatment performance to minimize disposal of toxic analytical waste. J Environ Sci Health Part A Toxic Hazard Subst Environ Eng 45:1595-1600. https://doi.org/10.1080/10934529. 2010.506116

Elbadawy HA, Sadik WA, Elhusseiny AF, Hussein SM (2021) Design of economic photocatalytic system with low energy consumption, and high quantum yield, for the degradation of acid red 37 textile dye. Process Saf Environ Prot 148:1191-1206. https://doi.org/10. 1016/j.psep.2021.02.036

Estrada-Arriaga EB, Reynoso-Deloya MG, Guillén-Garcés RA et al (2021) Enhanced methane production and organic matter removal from tequila vinasses by anaerobic digestion assisted via bioelectrochemical power-to-gas. Bioresour Technol. https://doi.org/10. 1016/j.biortech.2020.124344

Ghaly MY, Ali MEM, Österlund L et al (2017) ZnO/spiral-shaped glass for solar photocatalytic oxidation of reactive red 120. Arab J Chem 10:S3501-S3507. https://doi.org/10.1016/j.arabjc.2014. 02.015

Hassani A, Khataee A, Fathinia M, Karaca S (2018) Photocatalytic ozonation of ciprofloxacin from aqueous solution using $\mathrm{TiO}_{2} /$ MMT nanocomposite: nonlinear modeling and optimization of the process via artificial neural network integrated genetic algorithm. Process Saf Environ Prot 116:365-376. https://doi.org/10. 1016/j.psep.2018.03.013

Janke L, Leite A, Nikolausz M et al (2015) Biogas production from sugarcane waste: assessment on kinetic challenges for process designing. Int J Mol Sci 16:20685-20703. https://doi.org/10.3390/ ijms 160920685

Kannan A, Upreti RK (2008) Influence of distillery effluent on germination and growth of mung bean (Vigna radiata) seeds. J Hazard Mater 153:609-615. https://doi.org/10.1016/j.jhazmat.2007.09. 004

Khalik WF, Ho LN, Ong SA et al (2017) Optimization of degradation of Reactive Black 5 (RB5) and electricity generation in solar photocatalytic fuel cell system. Chemosphere 184:112-119. https:// doi.org/10.1016/j.chemosphere.2017.05.160

Kumar A, Subash B, Krishnakumar B et al (2016) Synthesis, characterization and excellent catalytic activity of modified $\mathrm{ZnO}$ photocatalyst for RR 120 dye degradation under UV-A and solar light illumination. J Water Process Eng 13:6-15. https://doi.org/10. 1016/j.jwpe.2016.07.009

Lebron YAR, Moreira VR, Furtado TPB et al (2020) Vinasse treatment using hybrid tannin-based coagulation-microfiltration-nanofiltration processes: potential energy recovery, technical and economic 
feasibility assessment. Sep Purif Technol 248:117152. https://doi. org/10.1016/j.seppur.2020.117152

Li N, Tang S, Rao Y et al (2018) Improved dye removal and simultaneous electricity production in a photocatalytic fuel cell coupling with persulfate activation. Electrochim Acta 270:330-338. https:// doi.org/10.1016/j.electacta.2018.03.083

Long Z, Li Q, Wei T et al (2020) Historical development and prospects of photocatalysts for pollutant removal in water. J Hazard Mater 395:122599. https://doi.org/10.1016/j.jhazmat.2020.122599

Lops C, Ancona A, DiCesare K et al (2019) Sonophotocatalytic degradation mechanisms of Rhodamine $\mathrm{B}$ dye via radicals generation by micro- and nano-particles of $\mathrm{ZnO}$. Appl Catal B Environ 243:629-640. https://doi.org/10.1016/j.apcatb.2018.10.078

Mohammadzadeh S, Olya ME, Arabi AM et al (2015) Synthesis, characterization and application of $\mathrm{ZnO}-\mathrm{Ag}$ as a nanophotocatalyst for organic compounds degradation, mechanism and economic study. J Environ Sci (china) 35:194-207. https://doi.org/10.1016/j.jes. 2015.03.030

Moussavi G, Hossaini H, Jafari SJ, Farokhi M (2014) Comparing the efficacy of UVC, UVC/ZnO and VUV processes for oxidation of organophosphate pesticides in water. J Photochem Photobiol A Chem 290:86-93. https://doi.org/10.1016/j.jphotochem.2014. 06.010

Nasir JA, Rehman Z, Shah SNA et al (2020) Recent developments and perspectives in CdS-based photocatalysts for water splitting. J Mater Chem A. https://doi.org/10.1039/d0ta05834c

Navgire M, Yelwande A, Tayde D et al (2012) Photodegradation of molasses by a $\mathrm{MoO}_{3}-\mathrm{TiO}_{2}$ nanocrystalline composite material. Cuihua Xuebao/chin J Catal 33:261-266. https://doi.org/10.1016/ S1872-2067(10)60298-7

Ong YP, Ho LN, Ong SA et al (2019) A synergistic heterostructured $\mathrm{ZnO} / \mathrm{BaTiO}_{3}$ loaded carbon photoanode in photocatalytic fuel cell for degradation of Reactive Red 120 and electricity generation. Chemosphere 219:277-285. https://doi.org/10.1016/j.chemo sphere.2018.12.004

Ong YP, Ho LN, Ong SA et al (2020) Comparative study of different polyatomic ions of electrolytes on electricity generation and dye decolourization in photocatalytic fuel cell. J Water Process Eng 37:101479. https://doi.org/10.1016/j.jwpe.2020.101479

Otieno B, Apollo S (2021) Energy recovery from biomethanation of vinasse and its potential application in ozonation post-treatment for removal of biorecalcitrant organic compounds. J Water Process Eng 39:101723. https://doi.org/10.1016/j.jwpe.2020.101723

Padilha RS, Ferrari-Lima AM, Seixas FL et al (2013) Evaluation of $\mathrm{ZnO}$ catalyst supported on zeolite $\mathrm{NaA}$ in the photocatalytic degradation of vinasse pretreated by coagulation/flocculation. Chem Eng Trans 32:823-828. https://doi.org/10.3303/CET1332138

Pandey DK, Soni P (1994) Distillery effluent - A potential resource for irrigating forest seed beds. Ambio 23:4-5

Petta L, DeGisi S, Casella P et al (2017) Evaluation of the treatability of a winery distillery (vinasse) wastewater by UASB, anoxic-aerobic UF-MBR and chemical precipitation/adsorption. J Environ Manag 201:177-189. https://doi.org/10.1016/j.jenvman.2017.06.042

Poblete R, Cortes E, Salihoglu G, Salihoglu NK (2020) Ultrasound and heterogeneous photocatalysis for the treatment of vinasse from pisco production. Ultrason Sonochem 61:104825. https://doi.org/ 10.1016/j.ultsonch.2019.104825

Prazeres AR, Lelis J, Alves-Ferreira J, Carvalho F (2019) Treatment of vinasse from sugarcane ethanol industry: $\mathrm{H} 2 \mathrm{SO} 4, \mathrm{NaOH}$ and $\mathrm{Ca}(\mathrm{OH})_{2}$ precipitations, $\mathrm{FeCl}_{3}$ coagulation-flocculation and atmospheric $\mathrm{CO}_{2}$ carbonation. J Environ Chem Eng 7:103203. https://doi.org/10.1016/j.jece.2019.103203

Qin Z, Liang Y, Liu Z, Jiang W (2011) Preparation of $\mathrm{InYO}_{3}$ catalyst and its application in photodegradation of molasses fermentation wastewater. J Environ Sci 23:1219-1224. https://doi.org/10.1016/ S1001-0742(10)60540-2
Ra A, Ikram M, Ali S et al (2021) Photocatalytic degradation of dyes using semiconductor photocatalysts to clean industrial water pollution. J Ind Eng Chem. https://doi.org/10.1016/j.jiec.2021.02.017

Rajamanickam D, Shanthi M (2014) Spectrochimica acta part A: molecular and biomolecular spectroscopy photocatalytic degradation of an azo dye Sunset Yellow under UV-A light using $\mathrm{TiO}_{2} /$ CAC composite catalysts. Spectrochim Acta 128:100-108

Ranjbari A, Mokhtarani N (2018) Post treatment of composting leachate using $\mathrm{ZnO}$ nanoparticles immobilized on moving media. Appl Catal B Environ 220:211-221. https://doi.org/10.1016/j. apcatb.2017.08.042

Rao AN, Sivasankar B, Sadasivam V (2009) Kinetic studies on the photocatalytic degradation of Direct Yellow 12 in the presence of ZnO catalyst. J Mol Catal A Chem 306:77-81. https://doi.org/10. 1016/j.molcata.2009.02.028

Reza KM, Kurny A, Gulshan F (2017) Parameters affecting the photocatalytic degradation of dyes using $\mathrm{TiO}_{2}$ : a review. Appl Water Sci 7:1569-1578. https://doi.org/10.1007/s13201-015-0367-y

Rizzo L (2011) Bioassays as a tool for evaluating advanced oxidation processes in water and wastewater treatment. Water Res 45:43114340. https://doi.org/10.1016/j.watres.2011.05.035

Rulli MM, Villegas LB, Colin VL (2020) Treatment of sugarcane vinasse using an autochthonous fungus from the northwest of Argentina and its potential application in fertigation practices. J Environ Chem Eng 8:104371. https://doi.org/10.1016/j.jece.2020. 104371

Santal AR, Singh NP, Saharan BS (2011) Biodegradation and detoxification of melanoidin from distillery effluent using an aerobic bacterial strain SAG 5 of Alcaligenes faecalis. J Hazard Mater 193:319-324. https://doi.org/10.1016/j.jhazmat.2011.07.068

Santana VS, Fernandes Machado NRC (2008) Photocatalytic degradation of the vinasse under solar radiation. Catal Today 133135:606-610. https://doi.org/10.1016/j.cattod.2007.12.131

Sarafraz M, Sadeghi M, Yazdanbakhsh A et al (2020) Enhanced photocatalytic degradation of ciprofloxacin by black $\mathrm{Ti}^{3+} / \mathrm{N}-\mathrm{TiO}_{2}$ under visible LED light irradiation: kinetic, energy consumption, degradation pathway, and toxicity assessment. Process Saf Environ Prot 137:261-272. https://doi.org/10.1016/j.psep.2020.02.030

Sheikhmohammadi A, Nourmoradi H, Manshouri M, Asgari E (2020) Performance intensification of BzP photo-catalytic degradation through adding exogenous oxidant. Optik (stuttg) 202:163571. https://doi.org/10.1016/j.ijleo.2019.163571

Subash B, Krishnakumar B, Swaminathan M, Shanthi M (2013a) Synthesis and characterization of cerium-silver co-doped zinc oxide as a novel sunlight-driven photocatalyst for effective degradation of Reactive Red 120 dye. Mater Sci Semicond Process 16:10701078. https://doi.org/10.1016/j.mssp.2013.04.001

Subash B, Senthilraja A, Dhatshanamurthi P et al (2013b) Solar active photocatalyst for effective degradation of RR 120 with dye sensitized mechanism. Spectrochim Acta Part A Mol Biomol Spectrosc 115:175-182. https://doi.org/10.1016/j.saa.2013.06.027

Sun Y, Wang W, Zheng F et al (2020) Phytotoxicity of iron-based materials in mung bean: seed germination tests. Chemosphere 251:126432. https://doi.org/10.1016/j.chemosphere.2020.126432

Valerio ME, García JF, Peinado FM (2007) Determination of phytotoxicity of soluble elements in soils, based on a bioassay with lettuce (Lactuca sativa L.). Sci Total Environ 378:63-66. https://doi.org/ 10.1016/j.scitotenv.2007.01.007

Vineetha MN, Matheswaran M, Sheeba KN (2013) Photocatalytic colour and COD removal in the distillery effluent by solar radiation. Sol Energy 91:368-373. https://doi.org/10.1016/j.solener.2012. 09.013

Wu CH (2008) Effects of sonication on decolorization of C.I. Reactive Red 198 in UV/ZnO system. J Hazard Mater 153:1254-1261. https://doi.org/10.1016/j.jhazmat.2007.09.086 